\title{
The Effect of Teenage Pregnancy on Adolescents in Amassoma Community of Southern Ijaw Local Government Area of Bayelsa State
}

\author{
Agnes Ebi Maliki, PhD \\ Department of Educational Foundations, Niger Delta University \\ P.M.B. 071, Wilberforce Island, Bayelsa State, Nigeria \\ E-mail: agnesmaliki@yahoo.com
}

Received: March 31, 2011

doi:10.5539/ass.v8n1p62

\author{
Accepted: August 17, $2011 \quad$ Published: January 1, 2012 \\ URL: http://dx.doi.org/10.5539/ass.v8n1p62
}

\begin{abstract}
The study investigated the effect of teenage pregnancy among youths in Amassoma community (university town) in Southern Ijaw Local Government Area of Bayelsa State. The study adopted the descriptive survey research design involving 1000 youths. Three research questions were raised. Descriptive statistics was used to analyze the data collected. The results revealed that the age at which teenagers engage in sexual intercourse is too early, that low socio-economic status, cultural factors, permissiveness of parents, drop in moral values, and teenagers' sexual behaviours are causes of teenage pregnancy. Also that school dropout, low self esteem, unemployment and early parenthood were effect of teenage pregnancy. Based on the findings, recommendations and implications for counseling were made.
\end{abstract}

Keywords: Teenage, Teenage pregnancy, Counselling, Parents, Youths

\section{Introduction}

Teenage pregnancy is one of the most common problems among adolescents worldwide. Teenage pregnancy is defined as a teenaged or underage girl (usually within the ages of 13-19) becoming pregnant. The term in everyday speech usually refers to women who have not reached legal adulthood, which varies across the world, who become pregnant. In the same vein teenage pregnancy is formally defined as a pregnancy in young woman who has not reached her $20^{\text {th }}$ birthday when the pregnancy ends, regardless of whether the woman is married or is legally an adult age 14 to 21 , depending on the country (Wikipedia,2010).

Before this period in Amassoma, teenage pregnancies were the norm. When a young girl became sexually mature she was married off and soon accomplished that for which she is biologically designed, giving birth to the next generation. Each child born to a young girl normally is considered a blessing.

The situation is different now in Amassoma, girls are expected to become educated and, for many, have secure employment before they bear children. Education is considered to be a necessity for living in a complex, information-rich society, and young women today are involved in the work force at about the same rate as young men. Teenage pregnancies are considered not a blessing but a curse. This is so because most of the children of these pregnancies will grow up fatherless and at high risk themselves of various social and behavioural problems, the education and work lives of their mothers will be seriously impaired.

In Amassoma four in ten girls become pregnant at least once before reaching the age of twenty, with many babies born and children now entering their teenage years, the total number of teenage pregnancies is expected to increase significantly over the next decade.

The most alarming trend associated with teenage pregnancy concerns the decline of early marriage, in that in the $20^{\text {th }}$ century to the early 1990 s early marriage was practiced, that is; marriage at younger ages and more restricted sexuality. Today, some teenage pregnancies and teen births are to unmarried girls. These girls lack maturity, the skills, and the assistance that are necessary for good parenting. Teenagers are having more sex, at earlier ages and without the use of contraceptives. Guttmacher Institute (2004) revealed that 60 percent of girls have their first sexual intercourse before their $13^{\text {th }}$ birthday. Also Banerjee, Pandey, Dutt, Sengupta, Mondal, 
\&Deb (2009) asserted that early dating of boys and girls from age 12 is a contributing factor to teenage pregnancy since they indulge in sexual activities. Similarly, Miller (2006) posited that girls are having sex at early ages between 10-13 years. Lack of parental guidance is another cause of teenage pregnancy in that most people evade their children from talking about sex. In some cases, they provide false information regarding sex and discourage their children to participate in any informative discussion about sex (Colin, 2003)

Stanley and Swierzeski (2011) opined that teenage pregnancy is as a result of poverty. Also Popenoe (1998) revealed that teenagers that get pregnant are from low socio-economic status parents. Guttmacher Institute (2005) posited that economics may also be responsible for teenagers child bearing is heavily concentrated among poor and low-income teenagers and that while low-income youths may not intend to have a baby, they may not be sufficiently motivated to avoid pregnancy. Teenage girls who belong to the poor families are more likely to get pregnant.

Robin (2005) reported that American popular culture glorifies sex and ignores responsibility. Beginning in early childhood, young people are bombarded with sexual messages, at the same time, puritanical attitude restrict the availability of resources and frank discussions about sex. This is why teenagers engage in early sexual activities. Also Female Problem (2010) reported that in developing countries, teenage pregnancy is as a result of traditional roles and early marriage because teenage pregnancy is seen as a blessing from God. Locoh (2000) posited that in some societies, early and traditional gender roles are important factors in the rate of teenage pregnancy particularly in some Sub- Sahara African countries, early pregnancy is often seen as a blessing because it is proof of the young woman's fertility.

Sexual abuse is also one of the causes of teenage pregnancy. Rape as a sexual abuse has more effect in the life of teenage girls causing unwanted sex and teenage pregnancy (Health Ezine, 2009). Hsu (2010) asserted that between 11 and 20 percent of pregnancies in teenagers are direct results of rape, while about 60 percent of teenage mothers had unwanted sexual experiences preceding their pregnancy. Saewyc, Magee \& Pettingell (2004) in their study indicated a strong link between early sexual abuse and subsequent teenage pregnancy in industrialized countries. Up to 70 percent of women who gave birth in their teens were molested as young girls.

Tamkins (2004) posited that the burdens of early child bearing on disadvantaged teens are undeniable; they reported that educational failure is a negative effect of teenage pregnancy. Also Robin (2011) reported that teenage pregnancy results into school dropout. Also Gueorgueiva, Carter, Ariet, Roth, Mahan and Rsenick (2000) supported the above studies by posting that teenage mothers are more likely to drop out of school.

The effects of teenage pregnancies on children are that they grow up in poverty, they have more health problems, they suffer from higher rates of abuse and neglect, they drop out of school, and they become teenage mothers, commit delinquent acts and adult crimes and incur failed adult marriages and other relationships.

The purpose of this paper is to ascertain the age at which girls get pregnant, causes of teenage pregnancy and the effects of teenage pregnancy in Amassoma community.

\subsection{Rational for the study}

Morbidity, health and social problems from teenage pregnancy need not to be overemphasized. Teenage pregnancy has medical, psychological and social implications and can be for teenagers the beginning of social deviance. In Nigeria little or no studies have been conducted on teenage pregnancy. Therefore the study on the causes and effects of teenage pregnancy is highly relevant, as it will allow intervention to reduce risk behaviours among teenagers.

It is against this background that this study sought to ascertain the causes and effects of teenage pregnancies in Amassoma community of Southern Ijaw LGA of Bayelsa State.

To guide this paper therefore these questions were raised:

1. At what age do girls first get pregnant?

2. What are the causes of teenage pregnancies?

3. What are the effects of teenage pregnancies?

\section{Methods}

The design adopted for the study is the survey design.

The population of this study consisted of 22,560 youths of Amassoma Community. The sampling technique adopted for this study is simple random sampling technique. This meant that every youth in Amassoma had a 
chance of being selected as a subject in the sample. The sample was 1000 youths including both male and female.

The research instrument used for the study was a questionnaire titled "Teenage Pregnancy". The questionnaire was divided into 3 sections, section A contained the personal data of respondents, section B which contained 5 items that sought questions on causes of teenage pregnancy and section $\mathrm{C}$ contained 4 items that sought questions on the effect of teenage pregnancy.1000 copies of the questionnaire were administered to the respondents and retrieved the same day. The instrument was validated by experts (that is professors of Sociology, Psychology, Guidance\& Counseling and Measurement and Evaluation).The experts ensured face and content validity of the instrument.

The reliability of the instrument was determined by administering it to youths in Ogobiri a neighboring community to Amassoma who are not included in the sample. The pilot group was made up of one hundred youths. The reliability procedure used is the split half method to determine the internal consistencies of the items the data obtained was analyzed by separating the items into odd and even. A pair of scores was then obtained for each of the youths. The Pearson Product correlation co-efficient (R) was applied to obtain an $r$ value of .68 that was then corrected using the Spearman Brown correlation formula. A reliability correlation co-efficient of $\mathrm{r} .79$ was derived; an indication that the instrument is good enough to be used for the study.

Data collected were analyzed according to the items in the questionnaire. Simple percentage was used to analysis data.

\section{Presentation of Result}

$<$ Insert Table 1 here $>$

Result in Table 1 revealed the ages at which girls get pregnant. 100 respondents indicated that girls first get pregnant at between ages 9-12, 270 respondents indicated that girls first get pregnant at between ages 13-15 while 630 respondents indicated that girls first get pregnant between ages 16-19.

$<$ Insert Table 2 here $>$

Result in Table 2 revealed the causes of teenage pregnancy to include low socio-economic status, cultural factor, permissiveness of parents, and drop in moral values and teenagers' sexual behavior.

$<$ Insert Table 3 here $>$

Result in Table 3 revealed that effects of teenage pregnancy include the following: school dropout, low self-esteem, unemployment and early parenthood.

\section{Discussion}

Result indicated that the age at which teenagers engage in sexual intercourse is too early; this is supported by the work of Land (2009) that revealed that teenagers have been engaging in early sexual activity. Also, $56 \%$ of young women and $73 \%$ of young men today have had intercourse by age 18 , compared with $35 \%$ of young women and young men in the early 1970s one in 5 youth do not have intercourse before the age of 20 (Guttmacher Institute, 2005).

Result also revealed that low socio-economic status of parents causes teenage pregnancy. This result is supported by the work of Popenoe (1998) which revealed that teenagers who get pregnant are from low socio-economic status parents.

Result also indicated that cultural factors also cause teenage pregnancy this is because culturally girls are seen as instruments of procreation so parents are happy when their girls get pregnant.

Result indicated that parents are permissive that is why teenagers engage in early sexual activities resulting in teenage pregnancy.

Teenage sexual behavior was also indicated as a cause of teenage pregnancy, this is because teenagers are exposed to risky sexual behavior, and this is supported by the report of Female Problems (2010) that stated that some life circumstances place girls at higher risk of becoming teen mothers.

Result also indicated that school dropout is one of the effects of teenage pregnancy; this is so because when girls get pregnant they drop out of school. This result is supported by the report of Robin (2011) that revealed that educational failure and school dropout are negative effects of teenage pregnancy.

Result also indicated that low self esteem is a negative effect of teenage pregnancy; this is supported by the report of Robin (2011) that reported that low self-esteem is a negative effect of teenage pregnancy. 
Early parenthood was revealed as one of the negative effect of teenage pregnancy.

\section{Strategies to reduce teenage pregnancy}

Teenagers need encouragement to postpone sexual involvement and information on pregnancy prevention if they become sexually active.

Effective sex education programs can decrease sexual activity and increase contraceptive use among those already sexually active. This should be included in the school curriculum.

Young people need to hear strong and consistent messages about responsible sexual behavior. This can be done through parents, media, counselors, social workers, etc.

Parents should be given sexuality education so that they can in turn speak to their children about it. This can be done through public talk, seminars, workshops and symposia.

\section{Counselling Implications}

The study revealed that the effect of teenage pregnancy result in school drop- out, low self - esteem, unemployment and early parenthood. Hence, counselors should be involved in community counselling this could be done by organizing seminars, workshops, symposia on the causes, effects and prevention of teenage pregnancy in the community as this will go a long way in the prevention of teenage pregnancy.

Counsellors should recognize the growing numbers of teenage mothers and counsel them on the need of going back to school. Their parents should equally be counseled not to abandon them but to support them.

Peer education programmes should be organized in the community.

\section{Conclusion}

In Amassoma community, teenage pregnancy is as a result of traditional roles and early marriage, because teenage pregnancy is seen as a blessing and a proof that the young woman is fertile. In most cases, poverty contributes to this, when one does not have someone to take care of her at her early age.

Conclusively teenage pregnancy carries social stigma and it is mostly outside of marriage. It brings about high risk of poverty, illiteracy or lower educational levels and ones it happens, such a girl will ever have a mark that hinders her progress in future. Good moral code should be established for teenagers and that they should wait until they are adult before they become sexually active.

\section{Recommendations}

In view of the findings of this study, it is recommended that moral counselling with the use of Rational Emotive Behaviour Therapy and other related theories should be used as a strategy to prevent teenage pregnancy. Parents should provide conducive environment for their girl child. Concerted efforts should be made to properly give children sex education.

\section{References}

Banerjee, B., Pandey, G., Dutt.D., Sengupta, B., Mondal, M. \& Deb, S. (2009). Teenage pregnancy: A socially inflicted health hazard. Indian Journal of Community Medicine, 34(3), 227-231. http://dx.doi.org/10.4103/0970-0218.55289

Colin, A. (2003). Peer pressure and teen sex. Psychology Today, 20(2), 396-405.

Female Problems. (2010). Top 20 effects of teenage pregnancy. [Online] Available: www.herbal-home-remedies.com (March 7, 2011)

Gueorguieva, R.V., Carter, R.L., Ariet, M., Roth, J. Mahan, C.S. \& Rsenick, M.B. (2000). Effect of teenage pregnancy on educational disabilities in kindergarten. American Journal of Epidemiology, 154(3), 212-220. http://dx.doi.org/10.1093/aje/154.3.212

Guttmacher Institute. (2004). Sex and America's teenagers. [Online] Available: www.guttmacher.org (March 7, 2011)

Guttmacher Institute. (2005). Facts in brief: Teen sex and pregnancy. [Online] Available: www.guttmacher.org (March 7, 2011)

Health Ezine. (2009). What are the causes of teenage pregnancy? [Online] Available: www.top54u.com (March $7,2011)$

Hsu, G. (2010). Statutory rape. Family Research Council. [Online] Available: www.csa.za.org (March 7, 2011) 
Land, J. (2009). More cash for contraception as teenage pregnancy rate rises. Local Government, Health.

Locoh, T. (2000). Early marriage and motherhood in Sub-Sahara Africa. WIN News, 9.

Miller, K. (2006). Causes of teenage pregnancy. Children and Youth Review, 19(5/6), 341- 367.

Popenoe, D. (1998). Teen Pregnancy: An American Dilemma. Testimony before the House of Representative, Committee on Small Business, Subcommittee on Empowerment, Washington, D.C.

Robin, E. W. (2011). Teen pregnancy. [Online] Available: www.about.com (March 7, 2011)

Saewyc, E. M., Magee, L. L. \& Pettingell, S.E. (2004). Teenage pregnancy and associated risk behaviours among sexually abused adolescents. Perspective on Sexual and Reproductive Health, 36(3), 152-158. http://dx.doi.org/10.1363/3609804

Stanley, J. \& Swierzewski111, M. D. (2011). Teen pregnancy, consequences of teenage pregnancy. [Online] Available: www.healthcommunities.com (March 7, 2011)

Tamkins, T. (2004). Teenage pregnancy risk rises with childhood exposure to family strife. Perspective on Sexual and Reproductive Health, 36(3), 220-228.

Table 1. The age at which girls get pregnant result of simple percentage

\begin{tabular}{|c|c|c|}
\hline $\begin{array}{c}\text { Age at which girls get } \\
\text { Pregnant }\end{array}$ & No. of Respondents & $\%$ \\
\hline $9-12$ & 100 & 10 \\
$13-15$ & 270 & 27 \\
$16-19$ & 630 & 63 \\
Total & 1,000 & 100 \\
\hline
\end{tabular}

Table 2. Result of simple percentages of the causes of teenage pregnancy

\begin{tabular}{|c|r|r|r|r|r|}
\hline $\begin{array}{l}\text { Causes of teenage } \\
\text { pregnancy }\end{array}$ & Yes & $\%$ & No & $\%$ & Total \\
\hline $\begin{array}{l}\text { Low } \\
\text { socio-economic } \\
\text { status }\end{array}$ & 760 & 76 & 240 & 24 & 1000 \\
Cultural factors & 840 & 84 & 260 & 26 & 1000 \\
$\begin{array}{l}\text { Permissiveness of } \\
\text { parents }\end{array}$ & 920 & 92 & 80 & 8 & 1000 \\
$\begin{array}{l}\text { Drop in moral } \\
\text { Values }\end{array}$ & 960 & 96 & 40 & 4 & 1000 \\
\hline $\begin{array}{l}\text { Teenagers sexual } \\
\text { behaviour }\end{array}$ & 1000 & 100 & - & - & 1000 \\
\hline
\end{tabular}

Table 3. Result of simple percentages of the effects of teenage pregnancy

\begin{tabular}{|c|r|r|r|r|r|}
\hline $\begin{array}{l}\text { Effects of teenage } \\
\text { pregnancy }\end{array}$ & Yes & $\%$ & No & $\%$ & Total \\
\hline $\begin{array}{l}\text { School drop } \\
\text { out }\end{array}$ & 1000 & 100 & - & - & 1000 \\
$\begin{array}{l}\text { Low } \\
\text { self-esteem }\end{array}$ & 920 & 92 & 80 & 8 & 1000 \\
Unemployment & 910 & 91 & 90 & 9 & 1000 \\
$\begin{array}{l}\text { Early } \\
\text { parenthood }\end{array}$ & 1000 & 100 & - & - & 1000 \\
\hline
\end{tabular}

